\author{
Judul Buku : Kebenaran yang Hilang \\ Penulis : Farag Fouda \\ Penerjemah : Novriantoni \\ Penerbit : Balitbang Depag, Jakarta \\ Cetakan : Pertama, Desember 2010 \\ Tebal : xxi +191 halaman
}

\title{
SISI KELAM SEJARAH (POLITIK) ISLAM
}

\author{
Tamyizul Ibad \\ STIT Raden Wijaya Mojokerto \\ EMAIL: tamyizuli@yahoo.com
}

K eberanian mengungkap sisi kelam sejarah (politik) Islam telah menyeretnya ke dua anggota Jamaah Islamiyah di siang yang naas, 8 Juni 1992, menerjang tubuhnya. Seketika Fouda meregang nyawa.

Kematian tragis Fouda diilhami oleh perdebatan sengit dua kubu ideologis di Mesir, sekularis dan islamis, dalam rangka Pameran Buku Kairo pada bulan Januari 1992. Fouda adalah tokoh sentral kubu sekularis. Tema perdebatan itu tergolong klasik. Seputar hubungan agama dan politik, negara dan agama, penerapan syariat Islam, dan institusi khilafah. Konflik dua kubu ideologis ini sebenarnya telah berlangsung lama. Sejak tahun 1980-an dan kian meruncing di tahun 1990-an.

\section{Tumbal Hegemoni}

Dengan menghamparkan data-data historis kebrutalan rezim khilafah pasca mangkatnya Muhammad, Fouda getol menolak politisasi Islam dalam isu pembentukan negara Islam serta penerapan hukum syariat Islam di Mesir yang digaungkan kubu islamis. Dus, realitas sosial (masyarakat) Mesir yang plural menjadi 
kendala utama terwujudnya tuntutan kubu islamis tersebut.

Fouda terus membumikan pemikirannya, baik melalui debat publik, menulis buku, maupun berpolemik di media massa. Tapi, celaka tiga belas. Iklim keagamaan Mesir kian memanas dan tampil dengan paras yang garang. Puncaknya, tanggal 3 Juni 1992 sekelompok ulama Universitas al-Azhar mengeluarkan fatwa bahwa Fouda, berdasar pemikiran dan tulisannya, dianggap menghujat agama Islam dan, karena itu, telah murtad. Implikasi fatwa ini, Fouda adalah musuh Islam dan halal darahnya.

Dalam konteks ini, Fouda tidak sendirian. Banyak tokoh keagamaan yang segendang sepenarian. Sebut saja, misalnya, Nasr Hamid Abu Zayd. Ia juga ditakfirkan para ulama Kairo pada tahun 1992 akibat pemikirannya yang radikal dan menabrak arus mainstream pemahaman keagamaan. Beruntung ia tidak bernasib seperti Fouda karena segera hijrah ke Leiden Belanda.

Demikian halnya Najib Mahfuz. Sastrawan Sungai Nil yang menyabet Nobel kesusastraan pada 1988 ini juga menjadi korban kebrutalan konflik politikkeagamaan Mesir. Walau sempat ditikam berkali-kali oleh seseorang atas perintah Syekh Umar Abdurrahman pada 14 Oktober 1994, tapi ia tak senelangsa Fouda. Najib luput dari sergapan maut.

Rekam jejak pemikiran Fouda dapat ditelusuri dalam beberapa buku. Misalnya, Hiwâr Hawla al-'Almâniyyah (polemik seputar sekularisme), Qablas Shuqûth (polemik tentang formalisasi syariat), an-Nazîr (penelitian tentang bahaya ekstremisme beragama), al-Mal'ûb (tentang skandal pencucian uang dan bank syariah), al-Irhâb (mengupas asal-usul pemikiran terorisme), dan al-Haqîqah alGhâybah (kritik terhadap sejarah politik Islam).

Sayangnya, pemikiran revolusioner Fouda dalam buku-buku tersebut hingga kini dilarang beredar di pasar perbukuan Mesir. Persis seperti yang pernah dialami Pramoedya Ananta Toer di Indonesia semasa rezim tirani Orde Baru berkuasa, buku-buku Fouda menyebar secara terbatas dan dibaca sembunyi-sembunyi di bawah bayang-bayang ketakutan.

Di Indonesia pun, sosok dan pemikiran Fouda belum begitu membumi. Gaungnya masih kalah gelegar dengan tokoh pemikir Islam revolusioner lain seperti Syahrur, Arkoun, Nasr Hamid Abu Zayd, Fazlur Rahman, dan sebagainya. Maka, ketika buku berumbul Kebenaran yang Hilang ini terbit kita seperti ketiban bulan.

\section{Dekonstruksi Sejarah}

Buku yang diterjemahkan dari al-Haqîqah al-Ghâybah ini mengajak kita 
membuka kembali lanskap sejarah (politik) Islam pasca mangkatnya Muhammad, zaman al-khulâfa' ar-râsyidûn hingga runtuhnya khilafah Abbasiyah. Fouda tegas menolak adagium kesohor periode salafi sebagai “zaman keemasan Islam”. Alihalih demikian, bagi Fouda periode salafi adalah zaman biasa. Tak terlalu banyak pencapaian gemilang pada zaman itu. Justru anyir darah yang tumpah akibat pertikaian sesama saudara seiman adalah fakta sejarah yang tak terbantah.

Betapa tidak, kecuali Abu Bakar, ketiga khalifah sesudahnya mati terbunuh. Yang paling mengenaskan adalah Khalifah Usman. Ia tewas di tangan orang muslim sendiri. Jasadnya tertahan dua malam. Salah satu persendiannya dipatahkan. Sebagian kaum muslim menolak menyalati dan melarang dimakamkan di pekuburan Baqi. Di bawah lemparan batu, jasadnya dimakamkan di pekuburan Hisy Kaukab, area pekuburan Yahudi. (hal. 26-27)

Menurut Fouda, dengan mangkatnya Muhammad berarti periode Islam sesungguhnya telah sempurna. Dan, dimulailah periode umat Islam. Periode ini terkadang sangat mendekati Islam, bahkan bertaut dengannya. Namun tak jarang pula sangat jauh dari Islam, bahkan melarikan diri darinya. Karena itu, dalam setiap kondisi dan periode, sejarah sama sekali tidak suci sehingga memungkinkan untuk didekonstruksi. (hal. 3)

Konsepsi ini digunakan Fouda untuk mematahkan argumentasi kubu islamis tentang perlunya pembentukan negara Islam serta penerapan syariat Islam yang berkiblat pada periode salafi. Islam sebagai negara telah gagal dalam periode itu, sehingga yang terjadi adalah politisasi Islam dalam konteks kenegaraan.

\section{Keniscayaan Ijtihad}

Mengidealkan periode salafi sebagai formalisasi negara Islam tanpa mempertimbangkan miliu dan faktisitas yang melingkupinya adalah sebuah kecerobohan. Sementara saat ini muncul serangkaian problematika kontemporer sesuai dengan semangat zaman kekinian: bagaimana caranya agar upah meningkat sedangkan harga menurun bila syariat Islam diterapkan, bagaimana mengatasi persoalan pemukiman yang sangat kompleks, bagaimana menanggulangi utang luar negeri secara syariat, dan sebagainya. Mengacu fenomena itu jika ijtihad abad ke-2 hijriah tersebut diterapkan pada masa yang sudah berubah ini tentu akan membawa kehancuran. Maka, sangat diperlukan ijtihad kontemporer. Dan, salah satu aspek paling menarik dari pemikiran Fouda adalah konsepsi tentang ijtihad.

Sebagaimana ditegaskan Novriantoni (JIL, 14/3/2008), Fouda bersikukuh bahwa 
ijtihad adalah keniscayaan. Ketentuan-ketentuan agama memang "tetap", tapi kondisi kehidupan "terus berubah". Dan, dalam proses tarik-menarik antara teks agama "yang tetap" dan konteks zaman "yang berubah" itu, pasti akan muncul "bentukbentuk penyimpangan”. Dalam konsepsi Fouda, upaya mengubah sesuatu yang dianggap tetap itulah yang disebut ijtihad, bukan mempertahankan sesuatu yang dianggap tetap dengan argumen atau dalih-dalih baru atau konservatisme. Kesimpulan ini termasuk unik dan belum banyak dikemukakan orang.

Meski dimaksudkan Fouda untuk menghantam pertahanan ideologis kubu islamis dan nuansa iklim keagamanan Mesir begitu menguar, namun buku ini berhasil mendedahkan pemahaman keagamaan, terutama mengenai de(/re)konstruksi sejarah (politik) Islam periode salafi, yang benar-benar baru. Sayangnya, buku sebagus ini tidak dijual bebas di pasaran. Mungkinkah Balitbang Depag juga terimbas ketakutan serupa versi aslinya di Mesir? @ 